\section{Methods}

\section{Preparation of Pt clusters, hydrogen chemisorption and EXAFS}

One gram of carbon was impregnated with $2 \mathrm{ml}$ acetone containing $\mathrm{H}_{2} \mathrm{PtCl}_{6}$, drop by drop with vigorous agitation. The amount of $\mathrm{H}_{2} \mathrm{PtCl}_{6}$ in the solution was varied, depending on the desired metal loading. After being dried in a $60^{\circ} \mathrm{C}$ oven, the impregnated carbon sample was heated in a $\mathrm{H}_{2}$ flow while increasing the temperature from room temperature to $300^{\circ} \mathrm{C}$ over $2 \mathrm{~h}$. The sample was subsequently outgassed for $2 \mathrm{~h}$ at $300^{\circ} \mathrm{C}$, for the desorption of $\mathrm{H}_{2}$ from the resultant Pt clusters. Hydrogen adsorption isotherms were measured at room temperature, in situ on the Pt clusters, using a volumetric adsorption apparatus. The hydrogen chemisorption (the number of $\mathrm{H}$ atoms per $\mathrm{Pt}$ atom) was determined by the extrapolation of the adsorption isotherm in the range of $10-30 \mathrm{kPa}$ to zero pressure. For EXAFS, the sample that was outgassed at $300^{\circ} \mathrm{C}$ was cooled to room temperature and exposed to air. About $0.1 \mathrm{~g}$ of the powder sample was pressed into a disk $10 \mathrm{~mm}$ in diameter, using polyethylene powder as a binder, and subsequently treated with $\mathrm{H}_{2}$ at $80^{\circ} \mathrm{C}$. The EXAFS was measured at the Pt $\mathrm{L}_{\text {III }}$ edge at room temperature under $\mathrm{H}_{2}$ atmosphere ${ }^{26}$, using the BL 10B facility at the Photon Factory in Tsukuba. Analysis of the EXAFS data was carried out by standard methods using the UWXAFS2 program package as in ref. 19.

\section{Preparation of electrodes and electrocatalytic activity measurements}

Twenty milligrams of Pt/C powder and $0.40 \mathrm{ml}$ ethanol containing $5.0 \mathrm{wt} \%$ Nafion were ultrasonically dispersed in $100 \mathrm{ml}$ distilled water. A $30-\mu \mathrm{l}$ portion of the resultant ink was dropped onto an electrode surface, which was composed of a glassy carbon core, $3 \mathrm{~mm}$ in diameter; the surrounding insulation area was $6 \mathrm{~mm}$ in diameter. The ink was carefully dried in a $70^{\circ} \mathrm{C}$ oven so that Pt catalysts could be uniformly coated over the entire cross-section of the 6-mm diameter area. The electrocatalytic current was measured at room temperature and a rotating speed of 10,000 r.p.m., in $0.10 \mathrm{M} \mathrm{HClO}$ saturated with $\mathrm{O}_{2}$

Received 2 February; accepted 29 May 2001

1. Fan, S. et al. Self-oriented regular arrays of carbon nanotubes and their field emission properties. Science 283, 512-514 (1999).

2. Rueckes, T. et al. Carbon nanotube-based nonvolatile random access memory for molecular computing. Science 289, 94-97 (2000).

3. Planeix, J. M. et al. Applications of carbon nanotubes as supports in heterogeneous catalysis. J. Am Chem. Soc. 116, 7935-7936 (1994).

4. Rodriguez, N. M., Chambers, A. \& Baker, R. T. K. Catalytic engineering of carbon nanostructures. Langmuir 11, 3862-3866 (1995)

5. Dillon, A. C. et al. Storage of hydrogen in single-walled carbon nanotubes. Nature 386, 377-379 (1997)

6. Lin, J. Hydrogen storage in nanotubes. Science 287, 1929-1929 (2000).

7. Dresselhaus, M. S., Dresselhaus, G. \& Eklund, P. C. Science of Fullerenes and Carbon Nanotubes (Academic, San Diego, 1996).

8. Kyotani, T., Tsai, L.-F. \& Tomita, A. Formation of ultrafine carbon tubes by using an anodic aluminum oxide film as a template. Chem. Mater. 7, 1427-1428 (2000).

9. Thess, A. et al. Crystalline ropes of metallic carbon nanotubes. Science 273, 483-487 (1996).

10. Kruk, M., Jaroniec, M., Ko, C. H. \& Ryoo, R. Characterization of the porous structure of SBA-15. Chem. Mater. 12, 1961-1968 (2000).

11. Lettow, J. S. et al. Hexagonal to mesocellular foam phase transition in polymer-templated mesoporous silicas. Langmuir 16, 8291-8295 (2000).

12. Ryoo, R., Jun, S., Kim, J. M. \& Kim, M. J. Generalised route to the preparation of mesoporous metallosilicates via post-synthetic metal implantation. Chem. Commun. 2225-2226 (1997).

13. Jun, S. et al. Synthesis of new, nanoporous carbon with hexagonally ordered mesostructure. J. Am. Chem. Soc. 122, 10712-10713 (2000).

14. Ryoo, R., Joo, S. H. \& Jun, S. Synthesis of highly ordered carbon molecular sieves via templatemediated structural transformation. J. Phys. Chem. B 103, 7743-7746 (1999).

15. Kruk, M., Jaroniec, M. \& Sayari, A. Application of large pore MCM-41 molecular sieves to improve pore size analysis using nitrogen adsorption measurements. Langmuir 13, 6267-6273 (1997)

16. Kageyama, K., Tamazawa, J. \& Aida, T. Extrusion polymerization: catalyzed synthesis of crystalline linear polyethylene nanofibers within a mesoporous silica. Science 285, 2113-2115 (1999).

17. Radovic, L. R. \& Ridriguiz-Reinoso, F. in Chemistry and Physics of Carbon Vol. 25 (ed. Thrower, P. A.) 243-358 (Marcel-Dekker, New York, 1997).

18. Kinoshita, K. Carbon, Electrochemical and Physicochemical Properties (John Wiley \& Sons, New York, 1988)

19. Ryoo, R. et al. Application of the xenon-adsorption method for the study of metal cluster formation and growth on Y zeolite. J. Am. Chem. Soc. 114, 76-82 (1992).

20. Kordesch, K. \& Simader, G. Fuel Cells and Their Electrochemistry (VCH, Weinheim, 1996).

21. Peuckert, M., Yoneda, T., Dalla Betta, R. A. \& Boudart, M. Oxygen reduction on small supported platinum particles. J. Electrochem. Soc. 133, 944-947 (1986).

22. Poirier, J. A. \& Stoner, G. E. Microstructural effects on electrocatalytic oxygen reduction activity of nano-grained thin-film platinum in acid media. J. Electrochem. Soc. 141, 425-430 (1994).

23. Takasu, Y. et al. Size effects of platinum particles on the electroreduction of oxygen. Electrochim. Acta 41, 2595-2600 (1996)

24. Wasmus, S. \& Kuver, A. Methanol oxidation and direct methanol fuel cells: a selective review. J. Electroanal. Chem. 461, 14-31 (1999).

25. Yang, P., Zhao, D., Chmelka, B. F. \& Stucky, G. D. Triblock-copolymer-directed syntheses of large-pore mesospore silica fibers. Chem. Mater. 10, 2033-2036 (1998).

26. Huang, L. et al. Fabrication of ordered porous structures by self-assembly of zeolite nanocrystals J. Am. Chem. Soc. 122, 3530-3531 (2000).

27. Doshi, D. A. et al. Optically, defined multifunctional patterning of photosensitive thin-film silica mesophases. Science 290, 107-111 (2000).
28. Fan, H. Y. et al. Rapid prototyping of patterned functional nanostructures. Nature 405, 56-60 (2000)

29. Cho, S. J., Ahn, W.-S., Hong, S. B. \& Ryoo, R. Investigation of the platinum cluster size and location on zeolite KL with ${ }^{129}$ Xe NMR, XAFS, and xenon adsorption. J. Phys. Chem. 100, $4996-$ 5003 (1996).

Supplementary information is available on Nature's World-Wide Web site (http://www.nature.com) or as paper copy from the London editorial office of Nature.

\section{Acknowledgements}

R.R. thanks M. Nomura for helpful discussions on EXAFS measurement. This work was supported in part by the Ministry of Science and Technology through the Creative Research Initiative Program (R.R.), by the School of Molecular Science through the Brain Korea 21 Project (R.R. and J.K.), by the Korea Science and Engineering Foundation through the MICROS Center at KAIST (J.K.), and by CREST, Japan Science and Technology Corporation (O.T.).

Correspondence and requests for materials should be addressed to R.R. (e-mail: rryoo@mail.kaist.ac.kr).

\title{
The dating of shallow faults in the Earth's crust
}

\section{Ben A. van der Pluijm ${ }^{\star}$ Chris M. Hall ${ }^{\star}$, Peter J. Vrolijk $\dagger$, David R. Pevear $\dagger$ \& Michael C. Covey $\dagger$}

\section{${ }^{*}$ Department of Geological Sciences, University of Michigan, Ann Arbor, Michigan 48109, USA \\ $\dagger$ ExxonMobil Upstream Research Co., Houston, Texas 77252-2189, USA}

Direct dating of ductile shear zones and calculation of uplift/ exhumation rates can be done using various radiometric dating techniques. But radiometric dating of shallow crustal faulting, which occurs in the crust's brittle regime, has remained difficult $^{1-4}$ because the low temperatures typical of shallow crusted faults prevent the complete syntectonic mineral recrystallization that occurs in deeper faults. Both old (detrital) and newly grown (authigenic) fine-grained phyllosilicates are thus preserved in shallow fault zones and therefore their radiometric ages reflect a mixture of both mineral populations. Also, the loss of ${ }^{39} \mathrm{Ar}$ during neutron irradiation in dating of clay minerals can produce erroneously old ages. Here we present a method of characterizing the clay populations in fault gouge, using X-ray modelling, combined with sample encapsulation, and show how it can be used to date near-surface fault activity reliably. We examine fault gouge from the Lewis thrust of the southern Canadian Rockies, which we determine to be $\sim 52 \mathrm{Myr}$ old. This result requires the western North America stress regime to have changed from contraction to extension in only a few million years during the Eocene. We also estimate the uplift/ exhumation age and sedimentary source of these rocks to be $\sim 172$ Myr.

Dating of shallow faults is, among other things, critical for our understanding of crustal evolution, plate interaction and fault reactivation, but there are two obstacles to radiometric dating of clay-rich fault rocks: (1) ${ }^{39} \mathrm{Ar}$ recoil in ${ }^{40} \mathrm{Ar} /{ }^{39} \mathrm{Ar}$ chronology and (2) 'contamination' of samples from old, detrital material. The momentum transfer that occurs during the ${ }^{39} \mathrm{~K}$ (n.p.) $\rightarrow{ }^{39} \mathrm{Ar}$ reaction is sufficient to move a produced Ar atom about $0.1 \mu \mathrm{m}$ from the site of the original $\mathrm{K}$ atom, which, for clay minerals, can be much greater than the average grain thickness. Thus, one expects massive losses of ${ }^{39}$ Ar during neutron irradiation, which would lead to erroneously old ages. Vacuum-encapsulated irradiation has been developed as a solution to the recoil problem ${ }^{5-8}$. The second problem, a mixed age 


\begin{tabular}{|c|c|c|c|}
\hline Sample & $\begin{array}{c}\operatorname{l} \text { in } 1 / S \\
(\%)\end{array}$ & $\begin{array}{c}\text { Detr I } \\
(\%)\end{array}$ & $\begin{array}{c}\text { Ar/Ar(total) } \\
\text { (Myr) }\end{array}$ \\
\hline \multicolumn{4}{|c|}{ Bentonitic claystone at fault } \\
\hline $\begin{array}{l}\text { 104G-c } \\
104 G-m \\
104 G-f \\
104 G-f 2\end{array}$ & $\begin{array}{l}70 \\
83 \\
85 \\
85\end{array}$ & $\begin{array}{l}57 \\
21 \\
12 \\
12\end{array}$ & $\begin{array}{r}129.6 \pm 0.4 \\
81.3 \pm 0.4 \\
67.5 \pm 0.1 \\
67.2 \pm 0.2\end{array}$ \\
\hline \multicolumn{4}{|c|}{ Bentonitic claystone $10 \mathrm{~cm}$ from fault } \\
\hline $\begin{array}{l}\text { 102E-c } \\
\text { 102E-m } \\
\text { 102E-f } \\
102 E-f 2\end{array}$ & $\begin{array}{l}69 \\
80 \\
75 \\
75\end{array}$ & $\begin{array}{l}73 \\
39 \\
18 \\
18\end{array}$ & $\begin{array}{r}133.0 \pm 0.4 \\
94.6 \pm 0.4 \\
72.3 \pm 0.1 \\
72.0 \pm 0.3\end{array}$ \\
\hline
\end{tabular}

The table shows percentage of illite in mixed-layer illite/smectite (I/S), percentage of detrita (discrete, $2 \mathrm{M}_{1}$ ) illite (Detr I), and total gas Ar ages in Myr (Ar/Ar(total)) for three size fractions of fault gouge samples). Corresponding spectra are shown in Fig. 1.

resulting from the contribution of detrital (old) and newly formed (authigenic) phases, can be resolved through quantitative X-ray analysis of clay grain size populations in low-grade samples. Rather than (erroneously) assuming that little or no detrital material is left in very fine grain size fractions, we quantify the ratio of authigenic and detrital mica in different clay size fractions ${ }^{9,10}$. This ratio typically decreases with increasing grain size. These grain size fractions are subsequently prepared for Ar dating, which produces a different apparent age for each grain size population. Combined with knowledge of the percentage of detrital illite these apparent ages constrain the age of each end-member phase (that is, of authigenic and detrital clays).

The success of our approach is demonstrated in a suite of gouge samples from the Lewis thrust in the southernmost Canadian Rockies (Gould dome near Crowsnest pass) ${ }^{11-13}$. This site was selected because faulted mudstone and bentonite units produce excellent outcrops of clay-rich gouge and the geologic age of faulting is reasonably well defined. The oldest age for motion on this fault is defined by the age of the youngest footwall sediments, which are Maastrichtian in age $(\sim 65 \mathrm{Myr})$. The youngest age for thrusting in the area is based on stratigraphic and structural characteristics of early Eocene deposits and is limited by the age of normal faults that cut the thrust and associated middle Eocene epoch ( $\sim 48 \mathrm{Myr})$ deposits $^{11-13}$. To the south, in the Rocky Mountain foreland of Wyoming, the latest foreland thrusting is also considered to be early Eocene in age $\mathrm{e}^{13,14}$.

Three grain size fractions from two sites of the Lewis thrust near Crowsnest pass were prepared ${ }^{15}$. The properties of the samples are listed in Table 1 and the corresponding Ar spectra are shown in Fig. 1. Two samples were prepared from the finest grain size fraction and show excellent repeatability. X-ray diffraction analysis shows the Lewis thrust gouge samples to be mixtures of authigenic illite in illite/smectite and discrete detrital illite (mica). Transmission electron microscopy shows that smectite away from the contact is replaced by illite-rich mixed-layer illite/smectite and occasional discrete illite near the contact ${ }^{16}$. The Ar data similarly display features that are characteristic of mixed-layer illite/smectite age spectra. Ages start at approximately zero for the room temperature 'recoil' gas fraction, indicating that there was virtually no loss of radiogenic ${ }^{40} \mathrm{Ar}$ (ref. 17). Thus, the degree of ${ }^{39} \mathrm{Ar}$ loss due to recoil is based on the sample's structure and is not due to heating from neutron irradiation. After the recoil fraction, ages climb gradually to a level above the total gas age. ${ }^{39}$ Ar recoil may produce point defects in the clay crystal structure, and is therefore likely to induce enhanced diffusional loss ${ }^{18,19}$, which accounts for both the rise of ages from zero and an 'overshoot' in apparent ages in what might normally be considered a plateau segment. Plateau ages can therefore only be used with well crystallized (epizonal grade) illite, where the net loss of ${ }^{39} \mathrm{Ar}$ due to recoil is trivial. We also see evidence in the Ar spectra of increasing detrital mica with increasing grain size fraction. Gouge samples show distinctive high age zones at the hightemperature part of the age spectra, which is a feature also noted in synthetic mixtures of clay components ${ }^{8}$ and Gulf coast shale samples ${ }^{17}$.

Using modelling of X-ray spectra ${ }^{18}$, we determined the percentage of discrete (detrital) illite (of total illite: \%detrital $+\%$ authigenic $=$ $100 \%$ ) in each grain size population. Our previous efforts indicate that these estimates have a $1-3 \%$ error; in our analysis we have therefore used an average $\pm 2 \%$ error. Table 1 lists the data from three size fractions of the two gouge samples. In Fig. 2 we plot percentage detrital illite against the total gas age of the eight analyses

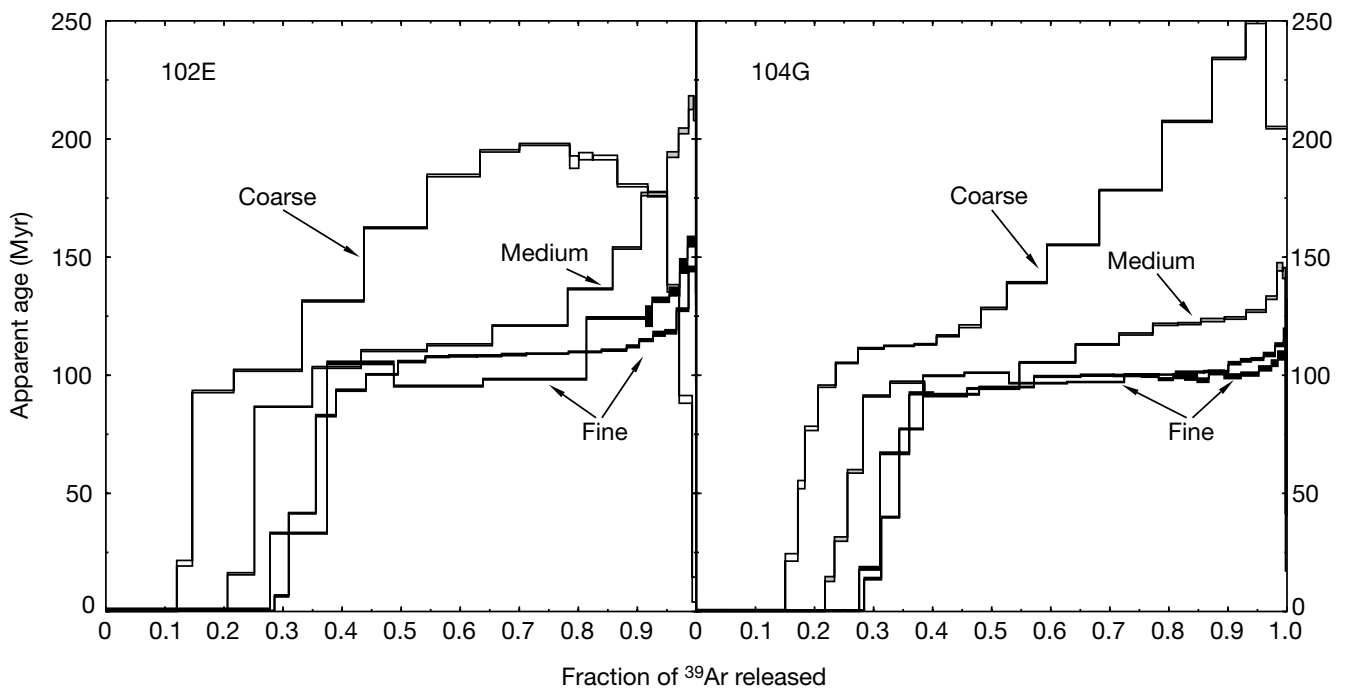

Figure 1 Representative Ar age spectra of clays in samples at the Lewis thrust for three grain size populations. The first fraction in each run is the gas released when the quartz capsule is broken, and represents the gas lost by the sample during neutron irradiation. This 'recoil' gas fraction is always nearly zero in apparent age, meaning that ${ }^{39} \mathrm{Ar}$ is released during irradiation due to recoil, but radiogenic ${ }^{40} \mathrm{Ar}$ is not. The amount of recoil ${ }^{39} \mathrm{Ar}$ varies from about $10 \%$ to $30 \%$ of the total, with the fine-grained samples having a higher percentage loss. This is expected, owing to their higher surface area to volume ratios, which tends to control the recoil loss mechanism. Apparent ages tend to increase at higher-temperature steps, especially in the coarse-fraction samples. We interpret this as representing the outgassing of relatively well crystallized mica from the host rocks. Fine fractions are $<0.02 \mu \mathrm{m}$ (black boxes), medium are $0.2-0.02 \mu \mathrm{m}$ (grey boxes) and coarse are $2-0.2 \mu \mathrm{m}$ (white boxes). Errors are $\pm 1 \sigma$. Sample numbers correspond to data in Table 1. 
of gouge and the best fit line through these data. The line is an errorweighted least-squares linear regression taking into account measurement errors in both the $x$ and $y$ coordinates. The actual fit was done on the function $\exp (\lambda t)-1$, which is a linear function of the radiogenic ${ }^{40} \mathrm{Ar}$ to $\mathrm{K}$ ratio.

Whereas we observe a large variation in the detrital illite component (ranging from $12-73 \%$ ) and total gas age (67-133 Myr) in the samples, the results plot along a well defined line with a high degree of precision $\left(R^{2}=0.96\right.$, mean of squared weighted deviates MSWD $=4.8$; Fig. 2). The quoted errors are $1 \sigma$ and include both a priori measurement errors and scatter about the best fit linear regression. Including error estimates for both detrital illite determination and standard Ar analysis error, we derive a lower intercept age at $0 \%$ detrital illite of $51.5 \pm 3.5 \mathrm{Myr}$ ago (early Eocene), which agrees well with geologic evidence for late movement on the Lewis thrust $^{13}$. The upper intercept of the regression line is calculated as $171.5 \pm 6.2 \mathrm{Myr}$ ago, which defines a sample containing $100 \%$ detrital material; that is, the 'age' of detrital micas. This middle Jurassic period age represents the mean age of uplift of the source terrain through the $\sim 280^{\circ} \mathrm{C}$ isotherm, which occurred during exhumation of the internal core of the Cordilleran orogen ${ }^{11}$. The approximate $52 \mathrm{Myr}$ age of latest contractional faulting in the Canadian Cordillera, combined with geologic evidence for the onset of regional extension soon afterward ${ }^{13}$, requires tectonic processes that allow a dramatic change in stress regime over a period of no more than a few million years. This supports the view that the onset of extension in the Cordillera reflects a change in slab-orogenic lithosphere coupling from delamination or a new subduction geometry ${ }^{20}$, rather than more gradual deeper mantle or lithospheric weakening processes.

Radiometric dating of near-surface faulting is possible by combined X-ray and Ar analysis of clay separates from fault gouge. X-ray analysis constrains the ratio of authigenic/detrital

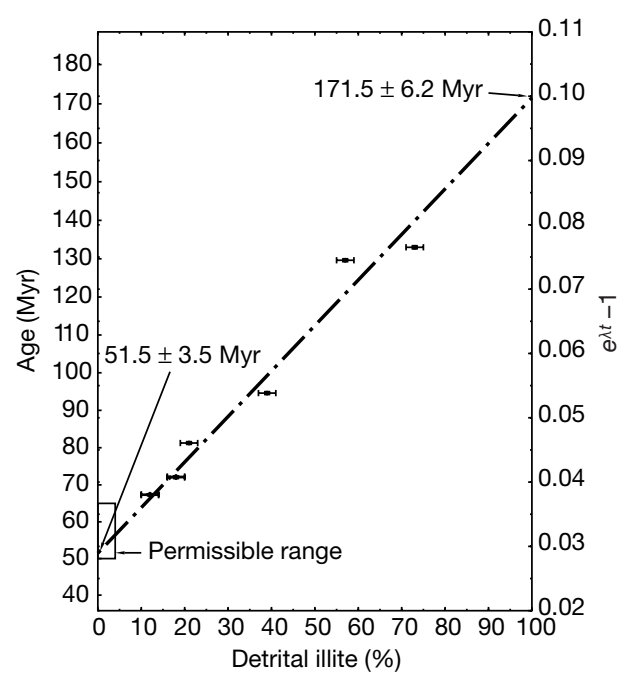

Figure 2 The Illite Age Analysis (IAA) plot correlates the percentage detrital component and age of a sample. The percentage of detrital illite in different grain size fractions is based on X-ray analysis of samples, for which we determine the corresponding Ar total gas ages. The function $\mathrm{e}^{\lambda t}-1$ is linearly proportional to percentage detrital mica and was used to fit the data; $\lambda$ is decay constant, $t$ is apparent age. The lower intercept of the best-fitting line at $0 \%$ detrital illite represents the age of faulting ( $~ 52$ Myr ago), whereas the upper intercept at $100 \%$ detrital illite represents the metamorphic/cooling age of micas in the exhumed source region ( $\sim 172 \mathrm{Myr}$ ago). The permissible range of thrust faulting in the sample area based on stratigraphic and cross-cutting relationships is indicated by the box. The age of faulting based on our analysis falls at the young end of this range. material, while modern Ar analysis permits radiometric dating of sub-milligram grain-size fractions. This approach extends reliable dating of crustal deformation to near-surface conditions, which will greatly facilitate the study of crustal evolution and regional tectonics. Because our method also gives the (cooling) age of the source area of the detrital material, it further adds the opportunity to constrain the uplift history and sedimentary source of continental regions.

\section{Methods}

In the vacuum-encapsulation method of Ar dating, the sample is in a fused silica vial that is evacuated to high vacuum and sealed. The capsule is then irradiated in a nuclear reactor and any recoiled ${ }^{39} \mathrm{Ar}$ is trapped within the capsule. In some applications, the whole capsule is fused and the experiment is functionally equivalent to a $\mathrm{K}-\mathrm{Ar}$ analysis. In others, the capsule is cracked under vacuum so that the recoiled gas could be analysed separately, and the samples are then step-heated. The percentage of recoiled ${ }^{37} \mathrm{Ar}$ (produced by ${ }^{40} \mathrm{Ca}(\mathrm{n}, \alpha) \rightarrow{ }^{37} \mathrm{Ar}$ ) is equivalent to the percentage of ${ }^{39} \mathrm{Ar}$ released ${ }^{6}$, despite the fact that ${ }^{37} \mathrm{Ar}$ is expected to travel about 2.5 farther than ${ }^{39} \mathrm{Ar}$ recoils, on the basis of conservation of momentum arguments (analogous to illite). We then realized that there is significant redistribution of recoiled $\mathrm{Ar}$ atoms from grain to grain, and that nanometrescale features determine retention of ${ }^{39} \mathrm{Ar}$. Illite from shales and bentonites of the Welsh Basin and New York State ${ }^{7}$, confirming earlier findings, show an excellent correlation between the illite XRD peak width $(\Delta 2 \Theta)$ and percentage of ${ }^{39} \mathrm{Ar}$ lost due to recoil. The $\Delta 2 \Theta$ value, called illite crystallinity, is a function of the mean illite diffracting domain thickness (that is, the average number of $1.0-\mathrm{nm}$ illite layers per particle or packet). The advantages of vacuum-encapsulated ${ }^{40} \mathrm{Ar} /{ }^{39} \mathrm{Ar}$ dating over the $\mathrm{K}$-Ar method ${ }^{9,10,21,22}$ are: (1) that it significantly reduces the sample size requirements from ten to hundreds of $\mathrm{mg}$ to sample sizes below $1 \mathrm{mg}$ for the ${ }^{40} \mathrm{Ar} /{ }^{39} \mathrm{Ar}$ method; (2) that it avoids possible 'nugget' effects, where the two separate aliquots for $\mathrm{K}$ and $\mathrm{Ar}$ analysis might not be representative of (sub-)milligram samples, because the ${ }^{40} \mathrm{Ar} /{ }^{39} \mathrm{Ar}$ method measures both radiogenic ${ }^{40} \mathrm{Ar}$ and ${ }^{39} \mathrm{Ar}$ (a proxy for $\mathrm{K}$ ) on the same sample; and (3) that the precision of analysis for ${ }^{40} \mathrm{Ar} /{ }^{39} \mathrm{Ar}$ is significantly better than for $\mathrm{K}-\mathrm{Ar}$ methods. Some studies have found that for pure illite or illite/muscovite samples, ages calculated omitting the recoil gas can correct for ${ }^{40} \mathrm{Ar}$ lost owing to structural defects. However, it was demonstrated that for mixedlayer illite/smectite this is an overcorrection ${ }^{17}$, and therefore we use the total gas age that includes the recoil gas fraction.

Our Illite Age Analysis (IAA) method capitalizes on the inherently variable ratio of the detrital and authigenic components in different grain size fractions. The detrital mica component is characterized by $2 \mathrm{M}_{1}$ polytype, whereas the authigenic form is $1 \mathrm{M}$ / $1 \mathrm{M}_{\mathrm{d}}$ polytype (typically mixed-layer illite/smectite) in low-grade shales and mudstones ${ }^{9} .2 \mathrm{M}_{1}$ mica is considered to be detrital clay as its crystallization temperature exceeds $\sim 280^{\circ} \mathrm{C}$ (ref. 23 ). The authigenic/detrital ratio is obtained through iterative modelling of the X-ray diffraction patterns of powdered samples using modified versions of the programs NEWMOD and WILDFIRE ${ }^{22,24-26}$. Using standard Stoke's Law settling techniques, we separate clay grain size fractions of $2-0.2 \mu \mathrm{m}, 0.2-0.02 \mu \mathrm{m}$ and $<0.02 \mu \mathrm{m}$, from which we determine the authigenic/detrital ratio through X-ray diffraction.

Received 14 June 2000; accepted 19 April 2001.

1. Murphy, P. J., Briedis, J. \& Peck, J. H. Dating techniques in fault investigations. Rev. Eng. Geol. 4, 153168 (1979).

2. Kralik, M., Klima, K. \& Riedmueller, G. Dating fault gouges. Nature 327, 315-317 (1987)

3. Gibbons, W. et al. Mylonite to megabreccia; tracking fault events within a transcurrent terrane boundary in Nova Scotia, Canada. Geology 24, 411-414 (1996).

4. Eide, E. A., Torsvik, T. H. \& Andersen, T. B. Absolute dating of brittle fault movements; Late Permian and Late Jurassic extensional fault breccias in western Norway. Terra Nova 9, 135-139 (1997).

5. Foland, K. A., Hubacher, F. A. \& Arehart, G. B. ${ }^{40} \mathrm{Ar} /{ }^{39} \mathrm{Ar}$ dating of very fine-grained samples: An encapsulated-vial procedure to overcome the problem of ${ }^{39}$ Ar recoil loss. Chem. Geol. 102, 269-276 (1992).

6. Smith, P. E., Evensen, N. M. \& York, D. First successful ${ }^{40} \mathrm{Ar}-{ }^{39} \mathrm{Ar}$ dating of glauconites: Argon recoil in single grains of cryptocrystalline material. Geology 21, 41-44 (1993).

7. Dong, H., Hall, C. M., Peacor, D. R. \& Halliday, A. N. Mechanisms of argon retention in clays revealed by laser ${ }^{40} \mathrm{Ar}-{ }^{39} \mathrm{Ar}$ dating. Sciences 267, 355-359 (1995).

8. Onstott, T. C., Mueller, C., Vrolijk, P. J. \& Pevear, D. R. Laser ${ }^{40} \mathrm{Ar} /{ }^{39} \mathrm{Ar}$ microprobe analyses of finegrained illite. Geochim. Cosmochim. Acta 61, 3851-3861 (1997).

9. Peaver, D. R. in Proc. 7th Int Symp. on Water-Rock Interactions (eds Kharaka, Y. K. \& Maest, A. S.) 1251-1254 (Balkema, Rotterdam, 1992).

10. Pevear, D. R. Illite and hydrocarbon exploration. Proc. Natl. Acad. Sci. 96, 3440-3446 (1999).

11. Price, R. A. in Thrust and Nappe Tectonics (eds McClay, K. R. \& Price, N. J.) 427-448 (Geological Society, London, 1981).

12. Fermor, P. Aspect of the three-dimensional structure of the Alberta Foothills and Front Ranges. Geol. Soc. Am. Bull. 111, 317-346 (1999).

13. Constentius, K. N. Late Paleogene extensional collapse of the Cordilleran foreland fold and thrust belt. Geol. Soc. Am. Bull. 108, 20-39 (1996).

14. Wiltschko, D. V. \& Dorr, J. A. Timing of deformation in the overthrust belt and foreland of Idaho, Wyoming, and Utah. Am. Ass. Petrol. Geol. 67, 1304-1322 (1983).

15. Vrolijk, P. \& van der Pluijm, B. A. Clay gouge. J. Struct. Geol. 21, 1039-1048 (1999).

16. Yan, Y., van der Pluijm, B. A. \& Peacor, D. R. Deformation microfabrics of clay gouge, Lewis Thrust, Canada: a case for fault weakening from clay transformation. Geol. Soc. Spec Publ. (in the press). 
17. Dong, H., Hall, C. M., Peacor, D. R., Halliday, A. N. \& Pevear, D. R. Thermal ${ }^{40}$ Ar $/{ }^{39}$ Ar separation of diagenetic from detrital illitic clays in Gulf Coast shales. Earth Planet. Sci. Lett. 175, 309-325 (2000).

18. Hall, C. M. et al. Dating of alteration episodes related to mercury mineralization in the Almadén district, Spain. Earth Planet. Sci. Lett. 148, 287-298 (1997).

19. Jaboyedoff, M. \& Cosca, M. A. Dating incipient metamorphism using ${ }^{40} \mathrm{Ar} /{ }^{39} \mathrm{Ar}$ geochronology and XRD modeling: a case study from the Swiss Alps. Contrib. Mineral. Petrol. 135, 93-113 (1999)

20. Bird, P. Formation of the Rocky Mountains, western United States: a continuum computer model. Science 239, 1501-1507 (1988)

21. Vrolijk, P., Covey, M. C., Pevear, D. R. \& Longstaffe, F. Dating clay-rich thrust faults. Geol. Soc. Am (Abstr. Progr.) 26, 466 (1994).

22. Pevear, D. R. \& Schuette, J. F. in Computer Applications to X-ray Diffraction Analysis of Clay Minerals (eds Reynolds, R. C. \& Walker, J. R.) 19-42 (Clay Minerals Society, Boulder, CO, 1993).

23. Srodon, J. \& Eberl, D. D. Review in Mineralogy (ed. Bailey, S. W.) 495-544 (Mineralogical Society of America, Washington, DC, 1984)

24. Grathoff, G. H. \& Moore, D. M. Illite polytype quantification using Wildfire calculated X-ray diffraction patterns. Clay, Clay Mineral. 44, 835-842 (1996).

25. Reynolds, R. C. WILDFIRE: A computer program for the calculation of three-dimensional X-ray diffraction patterns for mica polytypes and their disordered variations (Hanover, New Hampshire, 1994)

26. Reynolds, R. C. \& Reynolds, R. C. NEWMOD: A computer program for the calculation of onedimensional diffraction patterns of mixed-layered clays. (Hanover, New Hampshire, 1996).

\section{Acknowledgements}

D. R. Pevear has retired from ExxonMobil Upstream Research Company. We thank D. R. Peacor for assistance and several Cordilleran geologists for discussion, and the National Science Foundation and ExxonMobil Upstream Research Company for support of our fault gouge research.

Correspondence and requests for materials should be addressed to B.v.d.P. (e-mail:vdpluijm@umich.edu).

Geology and palaeontology of the Late Miocene Middle Awash valley, Afar rift, Ethiopia

\author{
Giday WoldeGabriel*, Yohannes Haile-Selassie $†$, Paul R. Renne $\ddagger$, \\ William K. Hart $\$$, Stanley H. Ambrosell, Berhane Asfawg, Grant Heiken\# \\ \& Tim White $\dagger$
}

${ }^{\star}$ EES-6/MS D462; and \# Institute of Geophysics and Planetary Physics, MS C303, Los Alamos National Laboratory, Los Alamos, New Mexico 87545, USA $\dagger$ Department of Integrative Biology and Laboratory for Human Evolutionary Studies, Museum of Vertebrate Zoology, 3060 VLSB, University of California, Berkeley, California 94720, USA

$\ddagger$ Berkeley Geochronology Center, 2455 Ridge Road, and Department of Earth and Planetary Science, University of California, Berkeley, California 94709, USA $\$$ Department of Geology, Miami University, Oxford, Ohio 45056, USA

II Department of Anthropology, University of Illinois, Urbana, Illinois 61801, USA 9 Rift Valley Research Service, P. O. Box 5717, Addis Ababa, Ethiopia

The Middle Awash study area of Ethiopia's Afar rift has yielded abundant vertebrate fossils $(\approx 10,000)$, including several hominid $\operatorname{taxa}^{1-4}$. The study area contains a long sedimentary record spanning Late Miocene (5.3-11.2 Myr ago) to Holocene times. Exposed in a unique tectonic and volcanic transition zone between the main Ethiopian rift (MER) and the Afar rift, sediments along the western Afar rift margin in the Middle Awash provide a unique window on the Late Miocene of Ethiopia. These deposits have now yielded the earliest hominids, described in an accompanying paper $^{5}$ and dated here to between 5.54 and 5.77 Myr. These geological and palaeobiological data from the Middle Awash provide fresh perspectives on hominid origins and early evolution. Here we show that these earliest hominids derive from relatively wet and wooded environments that were modulated by tectonic, volcanic, climatic and geomorphic processes. A similar wooded habitat also has been suggested for the $6.0 \mathrm{Myr}$ hominoid fossils recently recovered from Lukeino, Kenya ${ }^{6}$. These findings require fundamental reassessment of models that invoke a significant role for global climatic change and/or savannah habitat in the origin of hominids.

The western rift margin is more than $30-\mathrm{km}$ wide, and drops in elevation from greater than $2,500 \mathrm{~m}$ on the plateau to about $600 \mathrm{~m}$ at the rift floor. It is attenuated, with east-dipping, distinct arcuate antithetic morphology from fault displacement in a tectonic transfer zone between the NNW- and NNE-trending Red Sea and MER tectonic domains, respectively ${ }^{7,8}$ (Fig. 1, inset). Zones of broad warping along rift margins are typical of transfer zones in extensional regions such as the east African rift system ${ }^{7}$. The transfer zone is permeated by dike swarms ${ }^{9}$, and such magma flux and dike injection along steep boundary faults during rifting probably increased geothermal gradient, ductile deformation and crustal separation in the southern Afar rift margin. The close association between rifting and development of transfer zones exerts significant influence on structural patterns and synrift sedimentation ${ }^{7}$. The

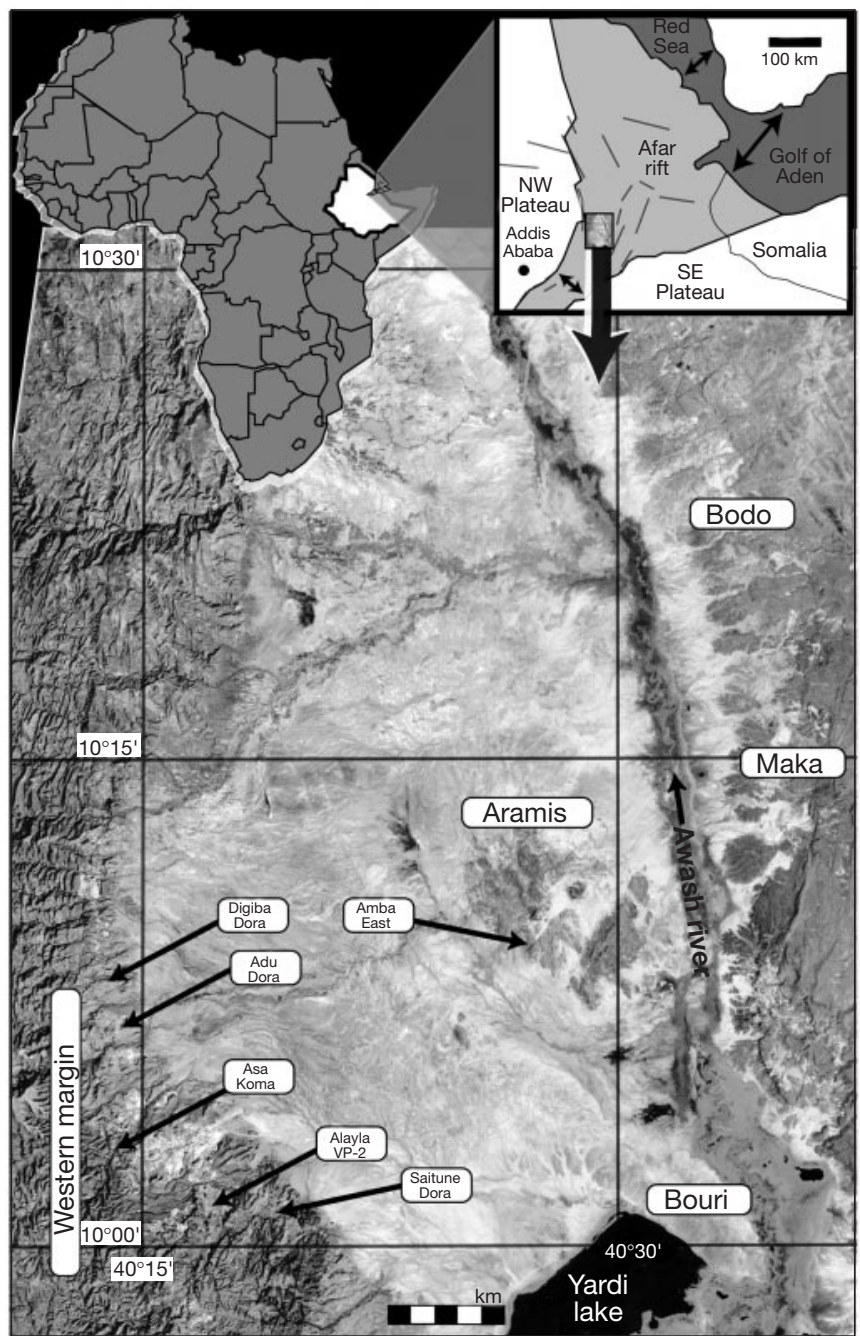

Figure 1 Location map showing measured sections along the western rift margin of the Middle Awash region of the southern Afar rift. Map based on Landsat Thematic Mapper imagery. Complex linear and arcuate NE-trending and transverse faulting is apparent along the rift margin. The broad rift margin and rift floor are shown by darker and lighter shades, respectively. Other hominid sites within the Middle Awash study area are located at Aramis (4.4 Myr; Ardipithecus ramidus), Maka (3.4 Myr; Australopithecus afarensis), Bouri (2.5 Myr; Australopithecus garhi) and Bodo (0.64 Myr; Homo). 